\title{
MEMÓRIAS DE UM TAMBORETE DE BAIANA: AS MUITAS VOZES EM UM OBJETO DE MUSEU
}

\author{
- JOSEANIA MIRANDA FREITAS \\ https://orcid.org/0000-0002-6133-2303 \\ Universidade Federal da Bahia \\ - LYSIE DOS REIS OLIVEIRA \\ https://orcid.org/0000-0002-0754-2780 \\ Universidade do Estado da Bahia
}

RESUMO Este texto, articulando literatura aos estudos sobre biografia dos sujeitos nos objetos, dá voz a um tamborete, peça do mobiliário do Museu de Arte da Bahia, localizado na cidade de Salvador, na Bahia, Brasil. Através das narrativas memoriais do tamborete, que aqui assume a ficcionalidade de um objeto animado que dialoga, as autoras discutem sobre a necessidade de revisão conceitual das exposições de arte decorativa, alertando para a importância de ampliar as informações relativas aos processos sociais relacionados à existência das coleções.

Palavras-chave: Biografia dos objetos. Mobiliário. Tamborete. Museu.

\section{ABSTRACT MEMORIES OF A BAIANA STOOL: THE MANY VOICES IN}

\section{A MUSEUM OBJECT}

This text, articulating literature with studies on subjects' biography in objects, gives voice to a stool, a piece of furniture from the Bahia Art Museum, located in the city of Salvador, in Bahia, Brazil. Through the stool's memorial narratives, which here assume the fictionality of an animated object that dialogues, the authors discuss the need for a conceptual review of decorative art exhibitions. They alert to the importance of expanding information in regard to the social processes related to the existence of collections.

Keywords: Biography of objects. Furniture. Wooden stool. Museum.

\section{RESUMEN MEMORIAS DE UN TABURETE BAIANA: LAS MUCHAS VOCES EN UN OBJETO DE MUSEO}

Este texto, que articula literatura a los estudios sobre biografía de los sujetos en los objetos, da voz a un taburete, un mueble del Museo 
de Arte de Bahía, ubicado en la ciudad de Salvador, Bahía, Brasil. A través de las narrativas memoriales del taburete, que aquí asume la ficcionalidad de un objeto animado que dialoga, las autoras discuten sobre la necesidad de una revisión conceptual de las exposiciones de arte decorativo, alertando sobre la importancia de expandir la información relacionada a los procesos sociales relacionados a la existencia de las colecciones.

Palabras clave: Biografia de objetos. Mobiliario. Taburete. Museo.

\section{Sobre biografia de objetos em}

\section{museu}

Quando uma pessoa morre, ninguém cuida da tristeza dos móveis!

(DIOME, 2008, p. 9)

Inspiradas pela leitura de Kétala, da escritora senegalesa Diome (2008), as autoras desta reflexão encontraram um caminho para autorizar a "fala" de um tamborete de baiana pertencente ao Museu de Arte da Bahia (MAB), localizado na cidade de Salvador. 0 romance de Diome narra, de forma ficcional, diálogos entre objetos inanimados (móveis e demais objetos pessoais) acerca da vida de sua recém-falecida proprietária enquanto aguardam a cerimônia do Kétala, na qual serão partilhados entre os familiares da protagonista da obra.

À inspiração de Diome foram acrescidas, principalmente, reflexões de Ingold (2018, p. 12), que aborda as relações de seres humanos e não humanos, que: “[...] estão constantemente nos inspirando, nos desafiando, nos dizendo coisas." O móvel aqui em questão, o tamborete de baiana, nos chamou atenção ao refletirmos sobre o centenário do MAB, em 2018, quando elaboramos um texto para sua publicação comemorativa. Despertamos para a potência informacional dos objetos e, mais especificamente, deste tamborete, dito "de baiana", que está em um espaço exposi- tivo sem sua referida "dona". Ocupa, hoje, um novo lugar, em sala representativa das ricas casas da Bahia colonial e imperial, ao lado de outro móvel (preguiceiro), como se vê na imagem a seguir.

Figura 1 - Preguiceiro. Jacarandá e Palhinha, Bahia, século XIX e Tamborete de baiana, Sebastião de Arruda, Jacarandá e Palhinha, Bahia, século XIX - 2a metade. (MAB, 1997, p. 319 e 310).

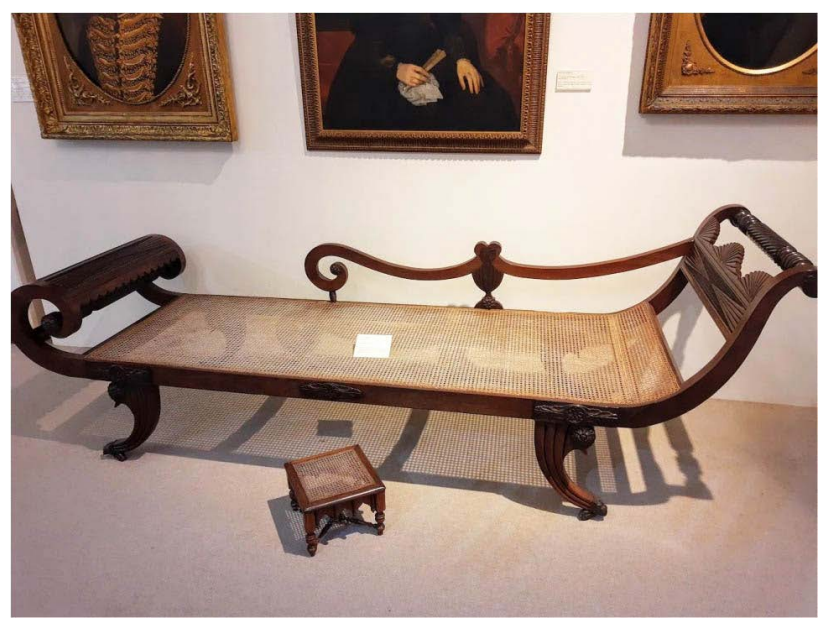

Foto: Sala de exposição do MAB. Acervo das autoras, 2019.

As poucas informações oferecidas ao público na etiqueta, encontradas nas fichas de documentação do Museu, e as do catálogo 
institucional, nos intrigaram a ponto de incitar uma investigação que trouxesse mais elementos sobre esse pequeno móvel. 0 material levantado condiz com a possibilidade de torná-lo protagonista, locutor de suas próprias memórias, entrelaçadas num conjunto especial de referências que passam pela História, Antropologia, Museologia, Literatura, Sociologia. Levantamos aqui indícios e argumentos para um texto não ficcional, sem abandonar, todavia, o universo sensorial e um tanto de imaginação, na pista que nos oferece o filósofo camaronês Mbembe (2018, p. 215), para o qual não há memória que “[...] num dado momento, não encontre sua expressão no universo do sensível, da imaginação e da multiplicidade".

Outra importante fonte de inspiração nos foi oferecida pelo inglês Gell, que na obra "Arte e agência" afirma que "[...] os objetos de arte equivalem a pessoas, ou mais precisamente, a agentes sociais" (2018, p. 32). Sua teoria apoiase no argumento de que:

O 'outro' imediato em uma relação social não tem de ser outro 'ser humano'. Todo o meu argumento depende dessa negação. A agência social pode ser exercida em relação às 'coisas', assim como pelas 'coisas' (e também animais). O conceito de agência social tem de ser formulado dessa maneira consideravelmente permissiva por razões empíricas, bem como teóricas. Acontece, claramente, que as pessoas formam relações sociais com as 'coisas' [...] (GELL, 2018, p. 32)

Esta dimensão de "agência" permitiu compreendê-la como anima, oferecendo a possibilidade de "fala" ao móvel de madeira, tendo como ponto de partida a sua materialidade implicada aos aspectos imateriais. Assim sendo, passemos diretamente à "fala" do tamborete de baiana ou, como é mais conhecido, "banquinho de baiana".
Figura 2 - Tamborete de baiana.

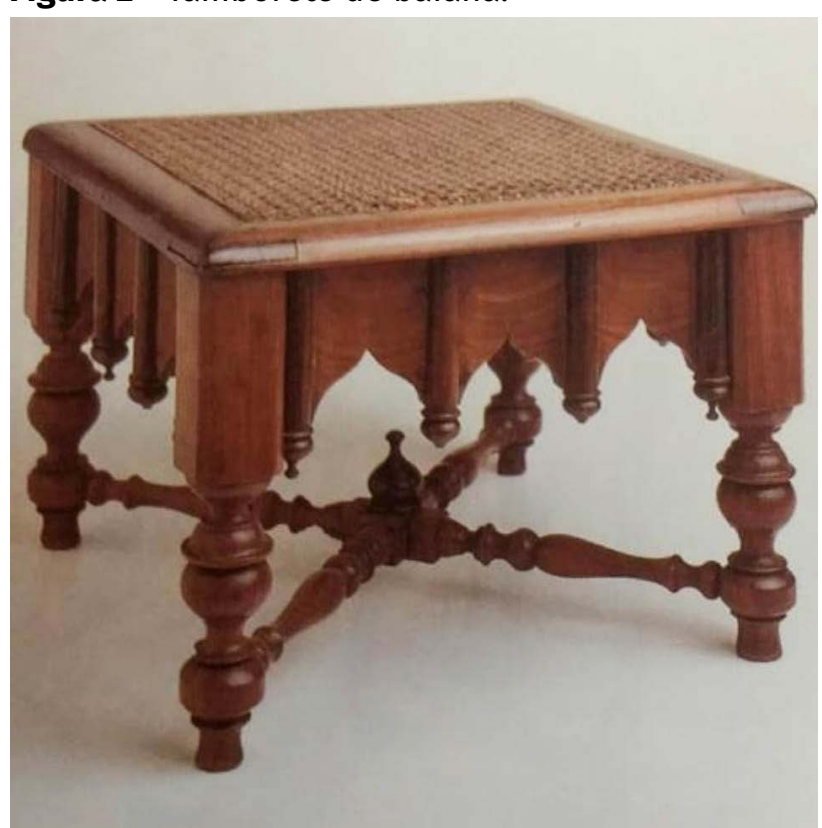

Foto: MAB, 1997, p. 310, fotógrafo Rômulo Fialdini.

\section{Memórias de um tamborete por ele mesmo}

Finalmente apareceram umas almas sensiveis neste museu e me permitem falar! Hoje sou um ser inanimado, mas já tive vida pulsante em seivas vegetais, fui um ser vivo; é bem verdade que do reino vegetal, mas isso não me tirou a percepção de vida vivida como tamborete.

$\mathrm{Na}$ minha anterior condição de ser vivo e na atual de inanimado habito, como diz Ingold $(2018$, p. 63) sobre uma certa escada de madeira, na: “[...] zona fronteiriça não entre a matéria e mente, mas entre substância e meio. A madeira está viva, ou 'respira', precisamente por causa do fluxo de materiais através da sua superfície". A romancista Fatou Diome e os antropólogos Ingold e Gell são os principais inspiradores para que eu, uma peça de museu, possa "voltar" à vida, já que parte dos "[...] fluxos geradores do mundo de materiais no qual [as coisas] vieram à existência e continuam a subsistir." (INGOLD, 2018, p. 63).

Sinto-me autorizado, então vou me apresentar, afinal, sou de um tempo em que os 
bons modos eram muito bem ensinados, disso tenho memória, assim como de muitas outras coisas que vou lhes contar! Diferentemente dos móveis e demais apetrechos narrados por Diome (2008), terei o privilégio aqui de falar sozinho e já os convido a moverem-se comigo pelas temporalidades, passado e presente. Convocarei personagens que me ajudarão a contar algumas das muitas histórias que esta minha vida de tamborete permitiu testemunhar e muito aprender.... Mas, mesmo assim, será uma narrativa lacunar, pois hoje não passo de um silenciado objeto.

Como peça de museu tive o meu rito iniciá- tico, se assim posso chamar, junto a duas obras de arte sacra que o meu proprietário, Hercílio de Souza Pimentel, vendeu ao Museu do Estado, hoje Museu de Arte da Bahia (MAB), no dia 9 de junho de 1948, conforme consta nos pareceres de compra exibidos abaixo, gentilmente cedidos pelo setor de Documentação do MAB. Como podem observar fui a peça mais cara, no valor de quinhentos cruzeiros, enquanto a imagem de Nossa Senhora das Candeias, em barro cozido, do século XVII, custou cem cruzeiros e a imagem de S. Francisco, em cedro, jacarandá e marfim, do século XVIII, custou trezentos e cinquenta cruzeiros, a moeda daquele período.

Figuras 3 - Documentos de compra de acervo do MAB.

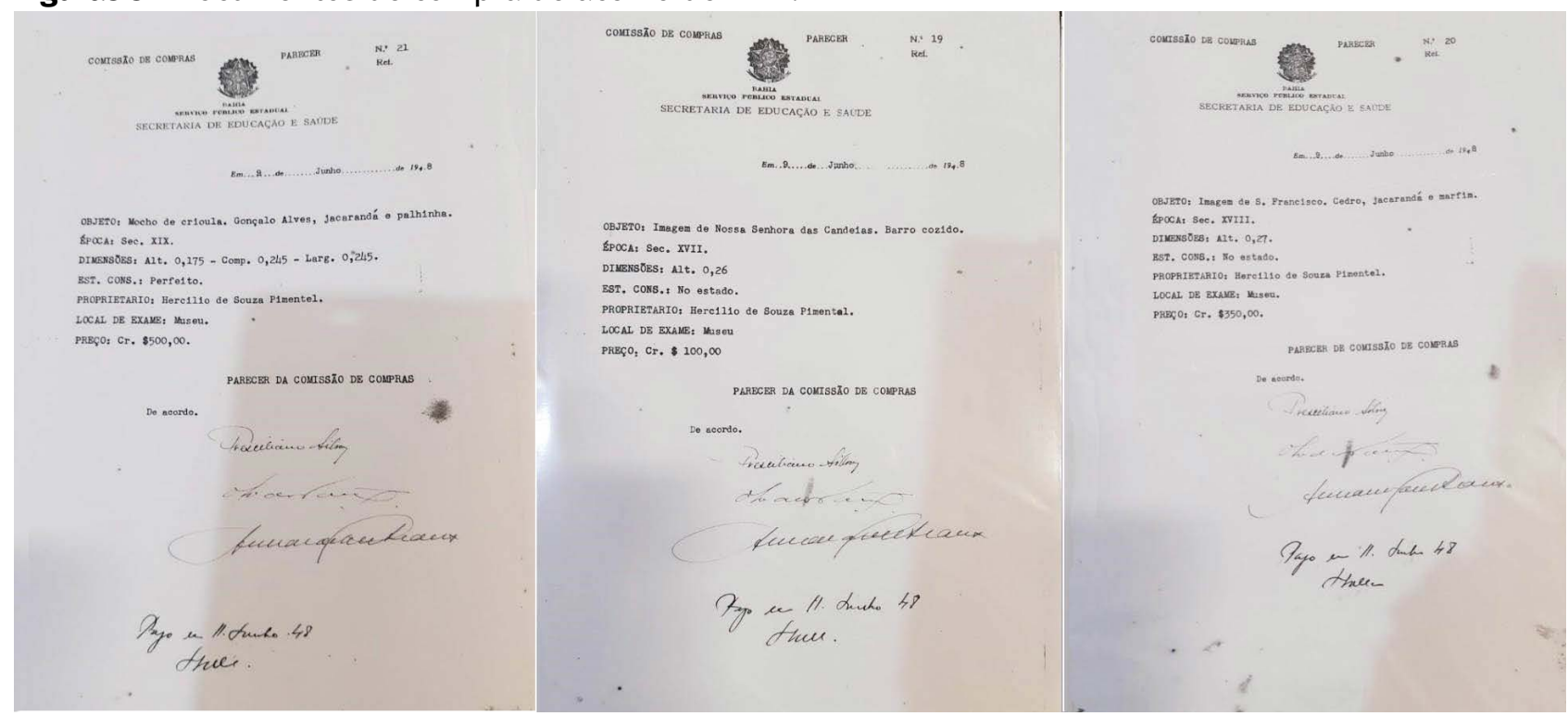

Fonte: MAB - Ficha do Setor de Documentação.

Notem que no parecer no 21 sou chamado de mocho ${ }^{1}$ de crioula, feito em madeira gonçalo-alves², jacarandá e palhinha. Já na minha primeira ficha, que assinala, de fato, minha entrada no Museu, recebi o número de identidade 48.25 , que permanece comigo. 0 registro

1 Mocho, também conhecido como banquinho, escabelo ou tamborete, conforme Tilde Canti: "Assento individual de tampo quadrangular com quatro pernas travadas, sem encosto e sem braços. [...] no século XVIII mocho seria sinônimo de escabelo [...] No Brasil encontramos o termo como sinônimo de tamborete raso." (CANTI, 1999, 259, grifos da autora).

2 "Árvore da família das anacardiáceas, madeira de lei do Brasil, parda, com veios escuros." (CANTI, 1999, 257). me adjetivou como "pequeno" mocho de vendedeiras - como eram chamadas as vendedoras em Portugal; já no Brasil do século XIX elas eram também conhecidas como ganhadeiras, disso falarei mais adiante. Nesta ficha, em lugar do gonçalo-alves com jacarandá verificaram que sou feito de sebastião-de-arruda, jacarandá e palhinha. Fui assim descrito pelo diretor do museu, José Valladares, no dia 15 de junho de 1948:

Pequeno mocho de crioulas vendedeiras. Sebastião de Arruda, jacarandá e palhinha. Bahia, seg. met. sec. XIX. Alt. 0,18 - comp. 0,24. 
Móvel de estilo Segundo Império, com influências vitorianas do 'Gotic revival', Ainda é usado pelas vendedeiras da cidade, mas sua delicada e paciente confecção indica o século XIX como data deste exemplar. Assenta sobre quatro pernas torneadas, entre si ligadas por aranha em $x$, também torneada, com bilro ornamental no centro. $O$ assento de palhinha, tem bordo liso, ligando as pernas babado re- cortado em ogivas, de superfície côncava e escavada e ligadas por pilastras terminadas em bilro. A peça tira partido do contraste entre a cor avermelhada do Sebastião de Arruda e o arroxeado do jacarandá - no bilro da aranha, no bordo do assento, nas pilastras e bilros do babado. Mocho semelhante foi publicado por Almeida Santos, com a mesma classificação, fig. 19.

Figuras 4 e 5 - Primeira ficha de documentação do tamborete, frente e verso.

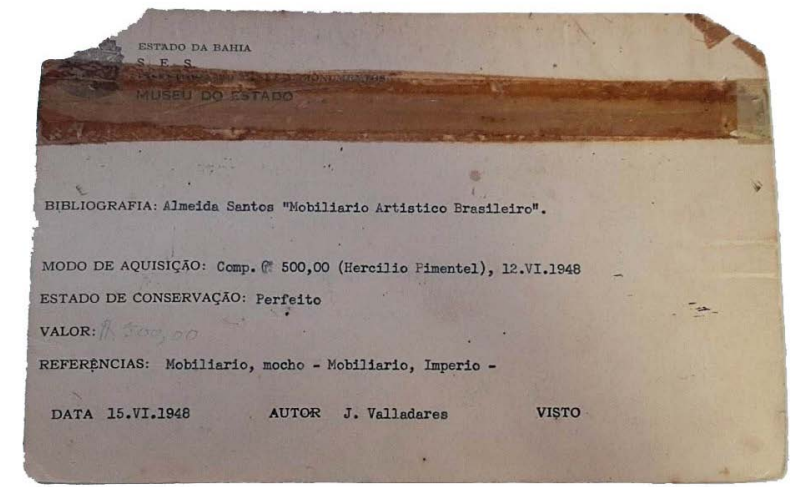

Fonte: MAB - Ficha do Setor de Documentação.

Como obra de referência para minha classificação, José Valladares, o autor da minha ficha, utilizou como fonte o livro "Mobiliário artístico brasileiro", de José de Almeida Santos, edição de 1944, que traz na p. 95 a ilustração número 19, que destaca a presença de um assemelhado tamborete, provavelmente um parente meu, que teve destino semelhante, ou seja, também estava numa sala compondo um cenário com um outro móvel: uma mesa de jogos, com característica de estilo do século XIX no Brasil, o estilo Império, tal como o preguiceiro que me acompanha.

Observem como esse tamborete é descrito (copiei, mas deixei a escrita como a daquele tempo):

[...] O pequeno mocho que vemos ao lado da mesa é do estilo Império e eram encontrados na Baía, servindo de assento às 'baianas' de taboleiro. A roda da sáia da vendedora de quitutes fórma em largo círculo e ela cruza as pernas na posição de Budha, permanecendo horas seguidas na atitude que nós não resistiríamos sinão por momentos. (SANTOS, 1944, p. 95)

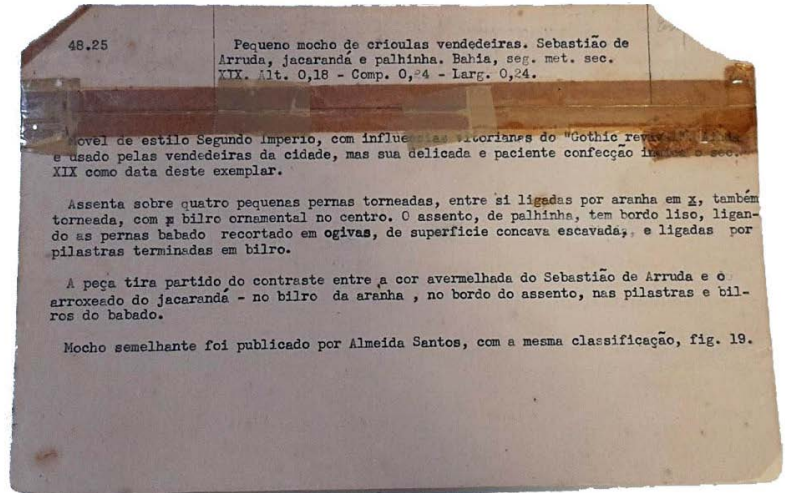

Figura 6 - Ilustração SANTOS, 1944, p. 95.

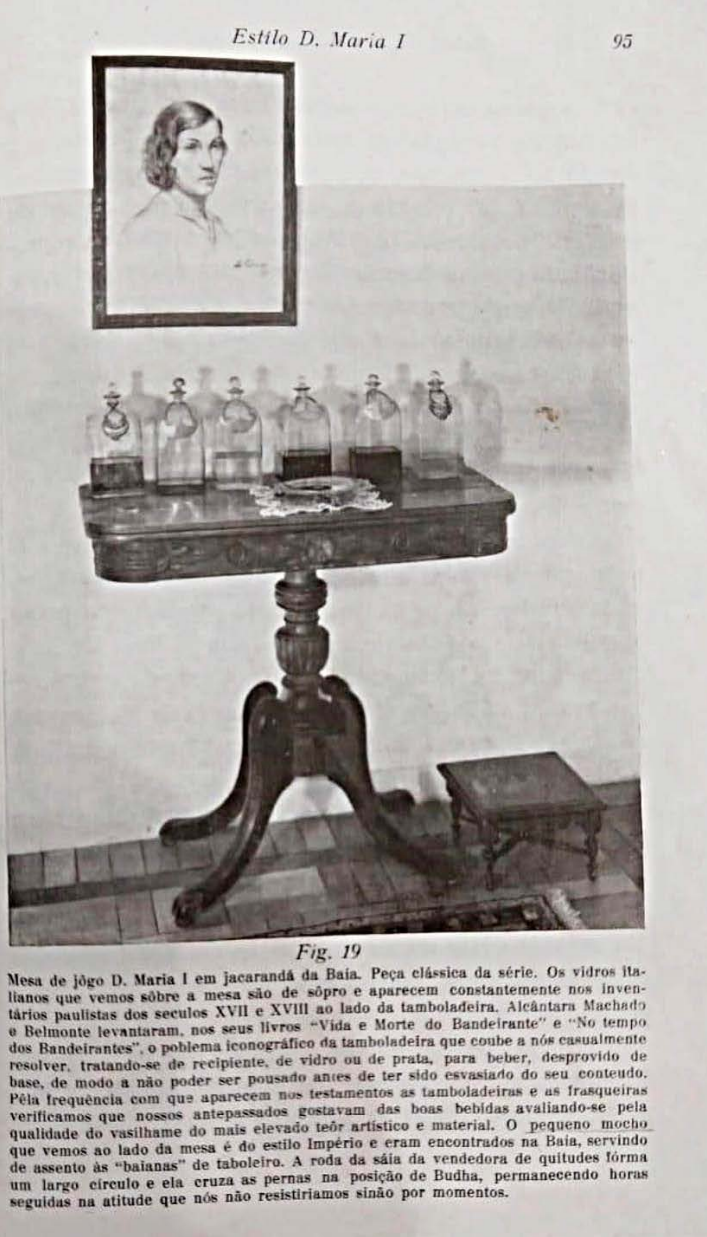

Foto: Lúcia Valois, bibliotecária MAB, 2019. 
Ao me deparar com essa descrição fui em busca de imagens para que vocês tivessem ideia de como eu e meus "parentes" éramos utilizados. Encontrei as imagens que estão na sequência (figuras 7 e 8) com baianas sentadas em tamboretes, publicadas na página do pesquisador Daniel Rebouças ${ }^{3}$, na rede social “Instagram". O pesquisador destaca o mercadejar nas ruas da Salvador nos anos 1920:

Mercadejar na rua. Salvador, cerca de 1920. [...] Membros da Marinha dos EUA, em viagem pela América por causa da Primeira Guerra Mundial, não tiveram como não registrar tais personas. [...]. Créditos: [...] The Vendor. Série ARA, (local não identificado). C. 1920. Library of Congress, New York City. (REBOUÇAS, 2019b)

O que mais me impressionou foi ter encontrado uma senhora exatamente na posição descrita por Santos (1944, p. 95): “[...] A roda da sáia da vendedora de quitutes fórma em largo círculo e ela cruza as pernas na posição de Budha, permanecendo horas seguidas na atitude que nós não resistiríamos sinão por momentos." - conforme a figura 7.

Figura 7 - "The vendor", Série ARA, (local não identificado). c. 1920. Library of Congress, New York City. (The vendor [...], c. 1920).

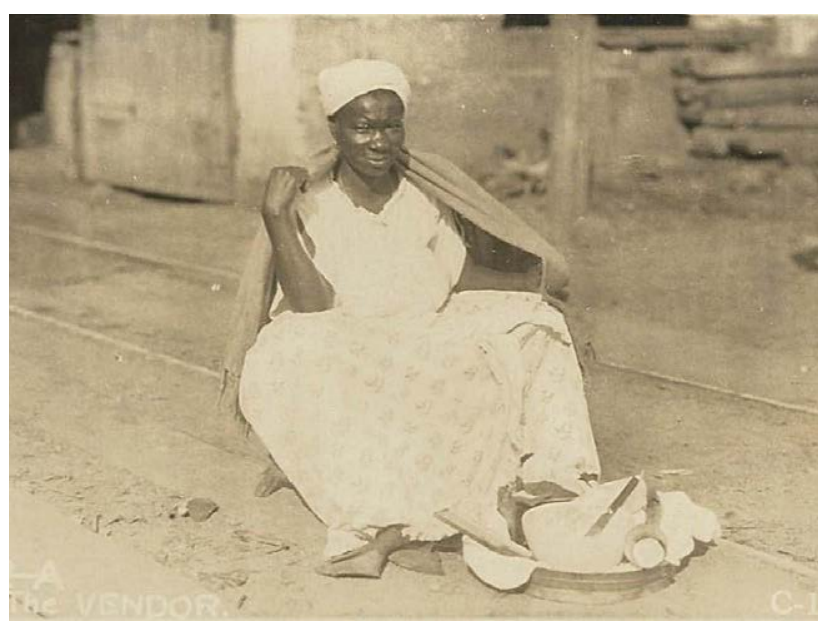

Foto: Disponivel em: https://www.instagram.com/ daniel.reboucas.historia/

3 https://www.instagram.com/daniel.reboucas.historia/
A segunda foto (figura 8), pertencente à "Coleção Ubaldo Senna Filho", foi enviada por Daniel Rebouças, através de correio eletrônico, com a informação de que esta imagem e uma outra (não publicada aqui) datam: “[...] de 1902 e fazem parte dos registros do fotógrafo chamado de Mercier, que esteve aqui em uma excursão da marinha francesa." (REBOUÇAS, 2019a).

$\mathrm{Na}$ foto, além do importante registro de uma cena de mercado no início do século XX, com muitas vendedoras e vendedores e seus produtos, destaco as senhoras na parte inferior à esquerda, que estão sentadas em tamboretes, meus antigos "parentes".

Figura 8 - "Le Marché", fotografia de Mercier.

(Bahia [...], 1902).

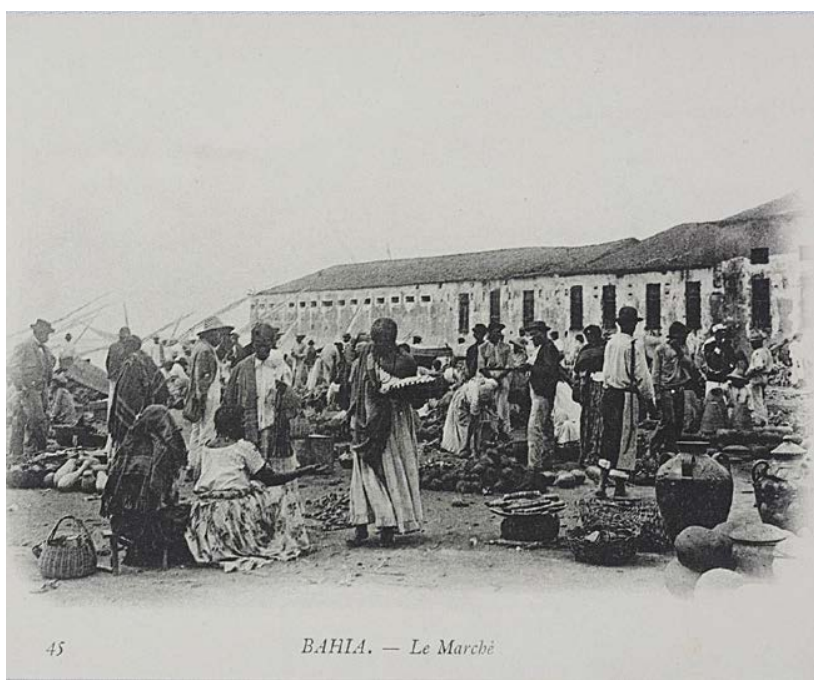

Foto: Coleção Ubaldo Senna Filho.

\section{Memórias de um tamborete:}

\section{sobre a minha serventia}

Diome (2008, p. 272) diz no seu romance que “[...] a honra de um móvel é servir [...]". Disso posso falar, e com prazer, mas vou começar lembrando o que o museu fala sobre a minha serventia: "Servia para descansar, ou mesmo, para pousar a cesta" - como aquele meu "parente" ilustrado no livro de Santos (1944) e nos registros fotográficos anteriores, nós, os pequenos tamboretes ou mochos, também ser- 
vimos para sentar. Vocês, humanos, não têm dimensão do que fazem com os objetos. Sobre essa relação dos humanos com os objetos é ainda Diome que me ajuda a explicar: “[...] Eles todos sabiam que quando os humanos veem uma cabaça quebrada ou um velho prato rachado, nem sonham as comidas suculentas que puderam conter" (DIOME, 2008, p. 272). 0 dito popular lembra que: "pirão comido é pirão esquecido", mas isso vale não somente para os pratos e talheres, mesas e cadeiras...

Voltando à minha serventia, como chama atenção Ingold (2018, p. 102), “[...] as funções das coisas não são atributos, mas narrativas. Elas são as histórias que contamos sobre elas". Histórias não me faltam aqui para contar, preciso somente organizar um pouco os assuntos, pois, afinal, fiquei muito tempo calado, memórias se misturam e para que vocês creiam em mim terei que continuar apresentando documentos e referências que certifiquem as minhas narrativas, buscando significados, pois estes não chegam à minha memória prontos. Como bem lembra Ingold (2018, p. 102): “[...] os significados das estórias não vêm prontos do passado, incorporados em uma tradição estática, fechada".

Vamos ao exercício de lembrar das minhas primeiras funções, já que no MAB estou exposto na última função. No tempo em que, de fato, eu era um tamborete de baiana - ou de crioula vendedeira -, em geral eu era carregado ao lado do corpo de belas mulheres africanas ou brasileiras (às vezes, nem sempre só mulheres), posição em que, além de escutar muitas conversas nos caminhos, becos e ruas desta cidade, eu podia apreciar a paisagem. Sobre essas belas mulheres, escreveu a professora Cecília Moreira Soares (1994, p. 49): “As escravas ganhadeiras, como se chamavam, eram obrigadas a dar a seus senhores uma quantia previamente estabelecida, a depender de um contrato informal acertado entre as partes".
Com esse dinheiro muitas compraram a sua liberdade, amealharam somas e bens que empregaram na educação dos rebentos ou destinaram a parentes e ajudantes após sua morte.

A rua era um espaço muito importante, pois, como também lembra Soares (1994, p. 2): era onde elas podiam ter "[...] possibilidades de vida mais autônoma." Sobre a autonomia dos seres humanos escravizados, Achille Mbembe, pontua que a humanidade “[...] é, por força das coisas, uma humanidade sustada, em luta para sair da fixação e da repetição, desejosa de entrar num movimento autônomo de criação" (2018, p. 94, grifos do autor). No caso das ganhadeiras e demais trabalhadoras e trabalhadores dos chamados cantos de trabalho, as vi criando diversas formas para ascender às mínimas condições de sobrevivência na sociedade escravista, chegando muitas vezes à aquisição da liberdade pela via da prática dos ofícios $^{4}$.

A cidade de Salvador e seus acervos, com suas memórias e histórias, possuem marcas indeléveis da construção das riquezas e opulências, baseadas no trabalho escravo. Não tem como apagar as memórias do trabalho escravo. Vejam bem em que situação me encontro! Eu, um pequeno mocho ou tamborete de vendedeiras, hoje faço parte de um cenário de salão requintado, que lembra as casas senhoriais, exatamente no local que antes esteve fincado o "[...] palacete do rico negociante de escravos José de Cerqueira Lima" (MAB, 1997, p. 12) - quantas voltas a vida dá! Que ironia do destino, não? Depois de ter saído das ruas com as vendedeiras terminei habitando esse cenário.

Há, no entanto, na minha trajetória de vida de tamborete, como coisa-objeto-artefato, uma perversa identidade com os seres humanos escravizados, pois eram também

4 Mais sobre este assunto, pode ser encontrado na obra de Lysie Reis (2012): “A liberdade que veio do ofício; práticas sociais e cultura dos artífices da Bahia do século XIX". 
considerados "coisas" para aqueles que detinham o poder econômico e político. As reflexões de Mbembe $(2019$, p. 30$)$ ajudam a meIhor explicar: "[...] Dado que a vida do escravo é como uma 'coisa', possuída por outra, sua existência é a figura perfeita de uma sombra personificada".

Entre "coisa" e "sombra personificada", das ruas cheguei ao meu proprietário, Hercílio de Souza Pimentel, que me vendeu no ano de 1948. Isso é o mais longínquo que posso chegar através das fontes documentais. Resta, então, muito por elucidar! Há mais, muito mais, minha última funcionalidade dá pistas de como nós, pequenos mochos, nos tornamos bancos auxiliares para melhorar a ergonomia das pessoas ao sentar-se. 0 museu explica: “[...] Com o passar do tempo foram integrados ao mobiliário da casa servindo de apoio aos pés" (MAB, setor documentação). Desculpem, mas assim parece muito fácil! Desculpem o linguajar, assim não pode ser! Assim tão simples! Dizer que fomos integrados e pronto. Será? Com a ajuda de Ingold (2018, p. 103) pode-se ir além na compreensão de que "[...] funcionalidade e narrativa são dois lados da mesma moeda". Minha funcionalidade inicial está atrelada ao corpo das baianas. Sobre esta categoria, o corpo, Ingold diz: "[...] é tanto biográfico quanto autobiográfico".

Por este viés, é dificil me ver sozinho no ambiente, pois na maioria das vezes estive com outros corpos, que estão para além das medidas que apresento. A meu lado estiveram vendedeiras, baianas ou ganhadeiras. Dessa forma, me sinto adequado, mas "fora do lugar", exposto nos salões das ricas casas. Onde estão as lindas baianas que me usavam para suas vendas nas ruas? Será que elas perguntam por mim? Hipoteticamente fui elaborado na segunda metade do século XIX, mas não carrego somente características do período, posso ter acompanhado algumas gerações dessas mulheres negras trabalhadoras, escravizadas, livres e alforriadas. O costume do uso de banquinhos, como eu, foi citado por Rocha ${ }^{5}$ (1977):

As mulheres sudanesas possuem pequenos bancos como objetos de uso pessoal. Conduzindo-os por todas as partes para onde se desloquem, no seu trabalho, comércio e obrigações de ordem social. 0 hábito de carregar o próprio banco foi conservado na Bahia, como prática dos escravos que não tinham assento nas igrejas e, já em nossos dias, em caráter popular, pelas baianas vendedoras de iguarias em tabuleiros. (ROCHA, 1977, p. 12)

Bom saber isto, não é mesmo? Eu não estava sozinho, nem nasci para ser banquinho de salão, ainda que eu tenha muitos parentes nesta função, muitos mochos e banquinhos auxiliares, para ajudar as pessoas no subir e descer, ou mesmo para colocar os pés e se sentirem mais confortáveis nas marquesas, divãs, canapés e todo tipo de sofá, que existia antigamente e ainda hoje. É uma função muito importante, disso me orgulho, não reclamo! Gosto do lugar que ocupo, gosto de ajudar as pessoas! Mas, como saímos das ruas para os salões?

Queixo-me dos segredos sobre a minha história. Há ainda questões a levantar, afinal, é a primeira oportunidade que tenho para falar depois de anos de sossego museal, depois de tantos anos na euforia das ruas, convivendo com os mais deliciosos cheiros dos quitutes das baianas. Tampouco tive notícias do meu amigo tabuleiro, éramos praticamente "unha e carne". Bastou me autorizarem a falar já estou atropelando os assuntos. Mas, compreendam a minha situação de anos de silêncio... Não lhes parece natural que muitos assuntos saltem de uma só vez?

Agora que sabem como me tornei peça desse museu, continuarei minhas histórias.

5 Foi diretor do Museu entre 1959 e 1974. (MAB, 1997). 
Hoje, exposto na sala do século XIX do Museu de Arte da Bahia, no primeiro andar desse imponente casarão conhecido como "Palácio da Vitória"6, depois daquela primeira ficha de documentação, na etiqueta da exposição e no Catálogo publicado em 1997 passei a ser chamado de "Tamborete de baiana":

TAMBORETE DE BAIANA - Sebastião de arruda, Jacarandá e Palhinha, Bahia, século XIX - 2a metade - $18 \times 24 \times 24$ cms. Conhecido como 'banquinho de baiana', era originalmente carregado pelas mulheres quando iam à rua vender alimentos. Servia para descansar, ou mesmo, para pousar a cesta. Com o passar do tempo foram integrados ao mobiliário da casa servindo de apoio aos pés. (MAB, 1997, p. 310, grifos do autor)

Acredito, assim como Ingold (2018, p. 67, grifos do autor), que é importante ter informações sobre os materiais que compõem o mobiliário, pois “[...] devemos, mais uma vez, levar os materiais a sério, pois é a partir deles que tudo é feito".

Agora vocês têm as primeiras noções sobre quem sou eu, sabem que fui feito com dois tipos de madeiras, sendo a mais avermelhada o "sebastião-de-arruda" e a mais arroxeada o "Jacarandá" e que também levo "palhinha" no meu assento, o que não somente me deixa mais leve para o ofício a que fui destinado como também, acreditem, me deixa mais elegante. Ou vão discordar? Desculpem a falta de modéstia, mas preciso aproveitar para exaltar as minhas qualidades.

Voltando às palhinhas, são muitas as histórias que essas tramas vegetais poderiam contar, sobre como e onde foram entrelaçadas ao meu corpo de duas madeiras, mas, infelizmente, essas memórias não as possuo, pois, geralmente, este tipo de informação não é oferecida quando uma peça é adquirida pelos museus.

6 O Museu passou a ocupar o casarão, em 5 de novembro de 1982, na gestão do artista visual Emanoel Araújo, entre os anos 1979 e 1983. (MAB, 1997).

\section{Memórias de um tamborete:}

\section{sobre minha feitura}

Os artífices que me fizeram, com suas mágicas mãos, possivelmente falavam sobre o lugar de onde as palhinhas tinham vindo, pois vieram de um lugar muito longe, que nem sequer o Atlântico passava por lá. Fica do outro lado da África, no Oceano Índico, num lugar chamado Índia, onde os portugueses aprenderam muitas técnicas e puderam observar e absorver um manancial artístico deslumbrante, que os influenciou a elaborar o famoso barroco português, segundo a estudiosa do mobiliário luso-brasileiro Canti (1999):

Da Índia vem o emprego de colunas internas vazadas e esculpidas à moda de marfim entalhado [...] Do intercâmbio entre Portugal e as Índias, surge, no panorama do mobiliário quinhentista europeu, o estilo indo-português. [...] artífices (sambladores e marceneiros) portugueses vão para Goa e Málaca, alguns lá permanecendo e outros voltando para Portugal com inovações para a decoração e a estrutura do móvel. [...] Entre as principais características dos móveis indo-portugueses assinalam-se a utilização do encaixe e de espigões de madeira (tarugo) resultando na ausência total de pregos e colas [...] (CANTI, 1999, p. 22, grifos da autora)

O uso da palhinha é resultado de um comércio triangular (Índia, Portugal e Brasil), em que intensas relações intercontinentais foram travadas para a difusão de técnicas e estilos artísticos. Foi usada em todos os estilos do período em que os portugueses mandavam nestas terras brasileiras, quero dizer, no período colonial e mesmo depois, no Brasil império, como é o meu caso, datado da segunda metade do século XIX. Mesmo sem exatidão quanto à data, as minhas características se aproximam dos móveis "[...] de estilo Segundo Império, com influências vitorianas do 'Gotic revival' [...]", como bem marcou o Valladares (1948). O final do século XIX e o início do século XX de- 
ram novas luzes a velhos estilos, numa perspectiva de Ecletismo. É preciso não perder de vista a recomendação de Ingold de que: “Nenhum objeto considerado puramente em si e por si, em termos de seus atributos intrínsecos apenas, [...] Descrever uma coisa [...] é colocá -la em relação com outras coisas [...]" (2018, p. 101, grifo do autor).

Da palhinha já falei, bem como, rapidamente, das madeiras, mas não falei das técnicas empregadas no trabalho de talha e torno que me embelezam. Talvez alguém se incomode por eu ser tão envaidecido, mas peço que compreendam, pois, afinal, tenho muitos anos de exibição pública, nos quais pessoas e grupos enalteceram as minhas aparências, fazendo com que me tornasse assim um tanto quanto vaidoso. Me permitam, ao menos neste texto em que as autoras autorizaram a minha fala, que eu deixe escapar as regras do uso de adjetivos!

Trago incorporado a junção de importantes traços estilísticos, a exemplo dos arcos de recorte ogival ${ }^{7}$ nas abas, formato que também se fazia presente nos tabuleiros, na arquitetura, na louça e em estampas diversas. Falando das minhas formas, pergunto, pois já não sei mais: o que se conta sobre aquelas pessoas que produziram os meus torneados, as partes talhadas e os trançados de palhinha? Que eu fui feito na Bahia está dito, mas onde teria sido: Salvador ou no Recôncavo? Essas e outras questões são mesmo dificeis de explicar. É engraçado, os museus, não somente o que habito, pouco falam sobre as pessoas que produzem os objetos. No entanto, algumas informações são apresentadas no capricho, como as minhas medidas, dados que vocês, humanos, salvo esportistas e modelos, não gostam muito de revelar.

7 O verbete, "ogiva" começou a ser usado a partir do século XVIII para designar o formato, com algumas variações que foram chamadas de arco ogival, arco de ogiva e, até mesmo, arco quebrado. No século XIX, com o ecletismo a ogiva gótica foi usada na arquitetura e demais artes.
Outra confissão, já que me autorizaram: parece que a história da minha vida ficou "estagnada" quando eu entrei neste museu e, como escreveu Alberti (2005), que defende que a incorporação de uma peça ao museu seja “[...] talvez, o evento mais significativo [...]." (p. 565), então, é sobre isso que quero falar e saber mais. Como deixei de ser acompanhante de belas damas rua abaixo, rua acima e fui parar num salão da elite baiana? Como disse lá no início, graças ao parecer no 21 sei como adquiri esse status tão importante de peça de museu, fui vendido pelo meu proprietário, valendo mais que peças de arte sacra (confesso que isto também me envaidece)! ${ }^{8}$

Para que vocês saibam de fato quem sou, será preciso saber mais do que a minha materialidade de objeto de museu. Guardo apreço pelos meus criadores, as mãos que me fizeram, me venderam, e pelas mulheres que me usaram para suas vendas e de tantas outras maneiras. Essas pessoas, sim, tiveram suas subjetividades, singularidades e pluralidades, que estão incorporadas a mim. Desses assuntos também os museus podiam falar, partindo dessas características que estão além da materialidade, que esteve impregnada naquelas mãos que me elaboraram e me usaram, e também naquelas que me levaram para o MAB. E lá dentro, quantas e quantas mãos me tocaram, estudaram, escreveram sobre mim? Afinal, como bem salienta Ingold: "As coisas são as suas relações" (2018, p 119, grifo do autor). Seguramente, a minha história institucional está repleta de memórias das muitas pessoas que se responsabilizaram por minha documentação, conservação, exposição e ações educativas. Seria bom que vocês pudessem saber e compreender quais foram os mecanismos que fizeram com que eu me transformasse em acervo museal.

8 Mais um assunto importante a ser elucidado, quais os critérios da precificação aquela época. 
Moles (1972, p. 77) me ajuda a explicar o que quero dizer, ao afirmar que: "em resumo, o museu é distanciado, frio, racional, longínquo, ele nos afasta do universo cotidiano do objeto, que é o que nos interessa [...]". É mesmo uma pena que os museus, no geral, ofereçam tão pouco ao público visitante. Falando do meu caso, as informações disponíveis ao público têm priorizado uma apreciação dos aspectos hegemônicos, cristalizados no período áureo das casas das elites, com base no modelo colonial, já no Brasil império, sem as devidas contextualizações, salvo nas visitas guiadas que, tenho que fazer justiça, as turmas do setor educativo capricham, explicam direitinho! Quanto a esse tipo de prática expositiva, já foi muito criticada pela museologia, e novas práticas estão sendo postas em diversos museus, mas, os museus de arte decorativa, notadamente, são mais resistentes às novas abordagens, exatamente pela natureza dos seus acervos, atrelados ao sistema econômico colonial escravista ${ }^{9}$.

\section{Memórias de um tamborete:} a experiência de me (auto)

\section{biografar, entrecruzando anônimas histórias}

A produção mobiliária de anônimos sujeitos, encomendada para as residências das ricas famílias da Bahia colonial e imperial, com seus grandes salões e quartos faustamente mobiliados, se transformou em um dos mais importantes acervos do MAB. Eu e os demais objetos artísticos utilitários nos transformamos na categoria "objetos de arte decorativa", em "patrimônios musealizados". No entanto, muitas vezes, se esquecem que carregamos, intrinsecamente, potencial para muitas investigações, como apontam os estudos sobre a construção

9 Mais informações sobre esta temática podem ser encontradas no artigo: "Escravidão: tema tabu para os museus de arte decorativa" (FREITAS, 2019). da "biografia cultural das coisas", proposta pelos antropólogos Appadurai (2008) e Kopytoff (2008). Nessas biografias é possivel explicitar e reconhecer as diversas memórias e vozes reveladoras de identidades dos sujeitos produtores, consumidores e preservadores, quer no passado, quer no presente.

A minha historicidade de objeto só tem sentido articulada à dimensão humana, isso não pode ser esquecido, por mais que me envaideça ao estar autorizado a falar. Vocês têm a possibilidade de nos estudar através da perspectiva de acervo museal, construindo análises sobre as biografias de sujeitos, através de nós, objetos, que via materialidade podemos revelar práticas do saber-fazer das artes mecânicas, numa dinâmica entre o passado e a contemporaneidade do mobiliário.

A cidade do Salvador, como primeira capital do país, teve um importante papel na produção das artes e ofícios entre o período colonial e o imperial, e parte dessa produção, relativa ao mobiliário, encontra-se em museus, a exemplo do $M A B$, que tem um significativo acervo que comprova a habilidade das produções lusas e baianas. Este tipo de produção na arte mobiliária, remanescente do passado, ou está musealizado ou em acervos particulares, ou mesmo à venda em antiquários. Nós, móveis desta categoria, não fomos produzidos em grandes séries, como faz hoje a indústria moveleira, somos objetos que, no passado, estávamos no cotidiano e hoje nos é atribuído o status de raridade.

É preciso considerar que a nossa história, de móveis de museus, está para além da mera vinculação aos estilos e à patrimonialização que recebemos como cultura material vinculada ao patrimônio imaterial. A nossa história está ligada aos dons individuais de sujeitos e suas práticas sociais. Alguns indivíduos consagravam-se por terem determinados requisitos, tais como o conhecimento de modelos clássi- 
cos, destreza nos desenhos, ou ainda a própria origem, como foi o caso, por exemplo, de alguns estrangeiros que haviam frequentado liceus de artes em seus países e aqui se apresentaram ou foram recebidos como artistas.

Mesmo diante da ausência desses profissionais, não faltavam móveis e $\operatorname{artefatos}^{10}$ que expunham um nível elevado de conhecimento técnico e artístico. Na maior parte deles, artistas, artífices e operários deram conta do traço e da execução, embora, em muitos casos, sua produção não se pautasse rigidamente nos cânones, nas regras e nos tratados artísticos. Para essas tipologias, recorria-se à cópia de modelos estrangeiros. No entanto, foi em maior dimensão que os artífices brasileiros executaram os requintados detalhes do barroco, do rococó e do neoclássico, no mobiliário, nos pisos de madeira com desenhos rebuscados em várias cores, tetos com entalhes e pinturas, portas de jacarandá delicadamente esculpidas etc., conforme apresenta Lysie Reis em suas obras (REIS, 2012 e 2019).

Os corpos de sujeitos trabalhadores(as), muitas vezes reduzidos à condição de "mão de obra", que deram conta dessa produção, também estiveram diretamente envolvidos com a produção da arquitetura e dos artefatos das edificações destinadas à habitação, ao comércio e a outros usos. Por ter sido adaptada aos materiais disponíveis, ao clima e à mão de obra que se formava, não teve um caráter internacional. Conquanto, não segue regras clássicas, essa produção promoveu, ao longo do tempo, uma reelaboração dos estilos ditos acadêmicos ou eruditos.

Como resultado disso, no mobiliário mais popular, como foi o meu caso de tamborete ou

10 Artefato pode ser definido tanto como o produto de trabalho mecânico, objeto, dispositivo, artigo manufaturado quanto como aparelho, engenho, mecanismo construído para um fim determinado. Artefato aqui está relacionado às imagens, peças do culto sacro, telas e todas as demais formas de cultura material ou produto deliberado da mão-de-obra humana. banquinho de baiana, também se incluíam ornatos, detalhes e um repertório simbólico que envolve tanto a criação como a adaptação de formas, vocabulários estilísticos, escala e cores nessa produção artística que compunha ambientes que denotam e identificam o que pode ser apreendido como popular, mas não isolado do erudito, visto que com ele dialoga. Sobre isso me parece interessante o conceito de circularidade cultural, presente nas obras de Mikhail Bakhtin (1987) e Carlo Ginzburg (2006), que julgo adequado a esta análise, uma vez que propõem a ideia de que as classes subalternas, ao entrarem em contato com a cultura das classes dominantes, filtram elementos desta, reelaborando-a a partir de suas próprias tradições.

O conhecimento dos mestres artífices das artes mecânicas respondia às necessidades dos que os contratavam, e este público não era somente composto por quem possuía muito dinheiro. Flexor (1974, p. 55) afirma que no Rio de Janeiro, “[...] combatia-se a distinção entre 'mechanicos' e os 'liberais' considerando que 'todas as artes uteis sam tanto mais nobres quanto mais necessárias para a mantença da sociedade'". Quase na virada do século, os dicionaristas Carvalho e Deus (1895) definiram arte como "[...] um conjunto de regras para fazer alguma coisa".

A investigação sobre o que produziu determinado grupo permite conhecer sua cultura, e vice-versa. Como postula Baxandall (1991), em seu estudo sobre pintura e experiência social na Itália da Renascença, as formas e os estilos refletem o ambiente social e os modos de ver de uma época. No entanto, tradicionalmente, a historiografia sobre a História da Arte no Brasil tem se restringido, em grande parte, à análise de objetos decorativos na sua dimensão física e/ou conceitual, e à análise dos artistas. Igual situação ocorre no campo da História da Arquitetura, dos arquitetos ou dos engenheiros 
oficiais. Deixaram-se de lado os executores: artistas, artífices e operários. Com isso, grande parte da própria cultura artística do passado é desconhecida, pois foi esse o contingente que produziu e continua produzindo a maior parte do que ainda é utilizado na história da humanidade. Queria mesmo saber sobre o lugar onde "nasci", sobre os sujeitos trabalhadores(as), com suas hábeis mãos que fizeram de mim um objeto tão útil, mesmo que agora esteja nessa posição de objeto de deleite, que também gosto, não me queixo! Não sei exatamente onde fui criado, mas posso seguir falando sobre esse mágico universo do mobiliário antigo de forma mais geral.

O sistema de corporações de oficiais portugueses que deu origem ao brasileiro, apesar de congênere, não foi semelhante, visto que no país a abundância de sujeitos escravizados(as), que durante três séculos conferiu outros rumos à história das corporações de ofícios, cuja existência e decadência estiveram intimamente ligadas à escravidão africana. Se, parafraseando Tinhorão (1988), “Os negros em Portugal" foram "uma presença silenciosa", o mesmo não pode ser dito sobre os negros no Brasil, que ocuparam suas mãos com os oficios mecânicos e suas mentes com a organização de estratégias capazes de abrir interstícios e permear diversos setores sociais, inclusive aqueles que os excluíam. Buscaram, através da união, obter fortalecimento, regalias, conhecimento e, principalmente, usaram o oficio para obter liberdades.

Ao considerar a "biografia cultural das coisas", tem-se como premissa que os objetos ou "coisas", bem como os seres humanos, habitamos um mundo social no qual tudo que existe tem uma relação indissociável. Matérias, ou coisas, e pessoas são parte de um mesmo universo. Existem em relações dialéticas, coisas (agora sem aspas) existem por causa dos seres humanos, e para eles e por eles são criadas, reproduzidas, utilizadas e guardadas. Por outro lado, a existência, permanência, ausência de nós objetos não se configura plenamente sem as imaterialidades dos humanos. Há uma interdependência funcional, cognitiva e até mesmo memorial; somos utilizados para os remeter ao passado.

Será preciso focar no conceito de circularidade e na biografia dos objetos como pressupostos teóricos metodológicos para elucidar, se não totalmente, mas de forma a iluminar, dados sobre a existência humana em nós objetos. É para essas complexas e importantes fontes de informações que nós objetos podemos oferecer que apontam as análises dos estudiosos Appadurai (2008), Kopytoff (2008) e Gell (2018). São alguns dos muitos que têm investigado o que vem sendo tratado como "biografia cultural das coisas", que também pode ser definida como biografia social das coisas -objetos. Essa é uma perspectiva teórico metodológica que se interessa pela variação, pela atribuição de significados às coisas não só a partir de sua forma, mas em como se deu a experiência humana com tais objetos. Como foi e é esse relacionamento? Especialmente, deve interessar aos humanos as diversas posições sociais que objetos ocuparam em suas vidas.

Isso implica, sob o ponto de vista do método, num alargamento da atenção: em primeiro lugar, uma investigação à construção dos seus significados, suas representações sociais e graus de importância cotidiana para as classes sociais. Como bem lembra Appadurai (2008), as coisas ou objetos têm uma vida social. Ao investigá-las, as pessoas poderiam nos perguntar: por quais mãos passamos (execução e circulação)? Como fomos usados? Como fomos guardados? Muitos de nós passamos por tentativas de destruição (tantos sucumbiram!), como tudo isso aconteceu? Se fomos arquivados e/ou musealizados, por quem? Por quê e como? Não seria um interrogatório rígido, mas 
um conjunto de perguntas poderia ser feito, afinal, a nossa materialidade oferece pistas interessantes, já salientadas várias vezes por aqui. Esse é um trabalho necessário, pois nós objetos oferecemos inúmeros indicativos de que temos muito a falar, muito mais do que dizem as reduzidas descrições das etiquetas museais.

Essas informações, entrelaçadas à produção de breves panoramas biográficos de sujeitos que nos produziram, utilizaram, preservaram e ainda preservam, seria uma tarefa possivel, acredito. Mesmo que não dê para falar exatamente sobre quem me produziu, possibilita compreender o ambiente da minha criação. Nós, objetos, sabemos que nem todos temos o privilégio de biografias individuais, e nisso nos assemelhamos às pessoas, elas também não. A estudiosa espanhola Ángela García Blanco (1994, p. 9), alerta que: “[...] cada objeto tem, pois, qualidade pessoal, uma personalidade própria, cada objeto se diferencia de outro e isto é tanto mais verdadeiro quanto mais nos distanciamos de nossa cultura industrializada"11.

As hábeis mãos das pessoas que me criaram, assim como outros objetos que chegam aos museus, geralmente são invisibilizadas, assim também são as demais pessoas com as quais tivemos algum relacionamento. Aquelas destacadas, de maneira geral, são os proprietários, e no nosso caso de móveis do MAB, a relação é sempre no masculino mesmo. A maioria de nós, mesmo tendo sido utilizado pelas esposas e filhas dos nobres, somos referenciados como pertencentes aos barões, condes e viscondes do Recôncavo açucareiro e da capital, Salvador.

A riqueza do mobiliário, expressa em cadei-

11 Tradução livre do original: “[...] Cada objeto tiene, pues, una cualidad personal, una personalidad propia, cada objeto se diferencia de otro y es tanto más verdad cuanto más nos alejamos de nuestra cultura industrializada." ras, bancos, camas, canapés, cômodas, cofres, arcas e mesas, é exibida sem contextualização com o seu ambiente de produção: as fazendas de plantação da cana-de-açúcar, nas quais o trabalho escravo era a força motora. Eu, meus companheiros móveis e demais objetos que lá estamos, fazemos parte de cenários expositivos que unem peças remanescentes de espólios familiares. Muitos móveis foram parar em antiquários, outros ainda habitam casas na capital e no interior, pois eram várias as casas que os nobres da Bahia possuíam, como lembra Pinho (1982, p. 442) 12

Não eram muito raros os casos de senhores de engenho possuírem, compostas e completas, duas ou três residências, com todos os atavios. Vindo-lhes um novo engenho, por herança ou compra, estava no brio do adquirente conservar a 'casa montada', ou ainda que a não habitasse, e escassamente a visitasse.

Foram necessários muitos móveis para compor as muitas casas das elites baianas, mas os museus esquecem de dizer que essas elites não duraram para sempre, muitos nobres faliram, não permaneceram no apogeu como sugerem os cenários expográficos, que nada falam dos processos de decadência das elites nobiliárquicas, retratadas nas muitas ruínas no Recôncavo Baiano, como também salienta Pinho: "[...] Numerosos sobrados vieram a arruinar-se abrigando apenas, por longos anos, um escravo velho de confiança, para guardar e vigiar o que ia dia a dia perecendo [...]" (PINHO, 1982, p. 442).

É mesmo uma pena que a nossa fala de objetos não seja percebida por vocês, pessoas humanas, pois poderíamos compartilhar os testemunhos, como fizeram os objetos no romance Kétala, bem exemplificada na fala da Máscara, objeto que coordenou os diálogos

12 Nesta obra, publicada originalmente em 1946, são apresentadas diversas ilustrações de objetos que atualmente se encontram nos museus de arte decorativa de Salvador. 
num determinado momento: “[...] visto não podermos impedir que os humanos nos dispersem, proponho que cada um de nós conte aos outros tudo que sabe [...] Assim, cada um de nós poderá partir para não importa que horizonte, mas com a história completa da nossa defunta dona" (DIOME, 2018, p. 23).

Assim como não sei como saí das ruas para os salões, tampouco sei detalhes sobre a minha manufatura, mas vou tentar fazer algumas aproximações, ainda que breves, com os sujeitos produtores do mobiliário no passado. Mesmo partindo de uma produção mobiliária anônima, vou, com minha memória material e com a ajuda das referências selecionadas, falar sobre sujeitos marceneiros e sobre umas poucas marceneiras na Bahia dos séculos XVIII e XIX. Espero que essas referências possam potencializar a força informacional que nós, acervos museais, temos. Ou seja, espero que possam criar mecanismos que explicitem as diversas vozes que nos compõem, e quem sabe possam oferecer novas interpretações sobre o patrimônio mobiliário.

Desde que os portugueses chegaram à cidade de Salvador - no início, oficiais lusos, e depois, no decorrer dos séculos, todo o tipo de estrangeiro -, constituíram, junto com os brasileiros que se tornaram mestres, oficiais e aprendizes, a mão de obra local para as "artes e oficios". Já nessa época o termo ofício designava o exercício por obrigação de algum tipo especializado de trabalho; o realizado manualmente e/ou com auxílio de instrumentos era conhecido como "ofício mecânico". O "oficial mecânico" também era chamado de "artista mecânico" ou artesão, derivando-se dessa designação as denominações de artista e artífice, verbetes que têm, entre dicionaristas dos séculos XVIII e XIX, acepções sobrepostas.

Dicionaristas dessa época apontam, em linhas gerais, que artífice e artista são termos imbricados. Podemos constatar isso em seus documentos, nos quais, correntemente, artífices se intitulavam de artistas ao nomearem suas associações, escolas e a si próprios, de acordo com Flexor (1974) e Leal (1996).

No Brasil, o uso corrente dos dois termos fez com que permanecessem imbricados e que a imprecisão vigorasse ao longo do século XIX, seja pela dificuldade de especialização dos indivíduos ou pela constatação de que os artífices executores eram também os criadores. A afirmação do renomado estudioso e artista Manoel Querino, de que "[...] a arte é a expressão de uma necessidade e não de um capricho" (1913, p. 1) talvez seja a que melhor explicite a visão que o sujeito das artes e ofícios tinha de sua atuação profissional.

Se o parâmetro para distinção entre artista e artífice fosse o ensino formal, no caso da experiência brasileira do século XIX poucos poderiam receber a qualificação de artista, haja vista a escassez de instituições de ensino destinadas às artes. Além disso, os currículos de instituições educacionais voltadas para a formação do artífice evidenciam, no conjunto das disciplinas oferecidas, a intenção de dotá-lo de uma capacidade tanto técnica quanto artística. Silva (1988) explica que para as camadas abastadas:

[...] o artista exercia mais uma função de lazer, enquanto o artífice o labor aplicado a uma razão pragmática, não só do que produzia, mas também para que produzia, isto é, o sustento, a sobrevivência. 0 que se pode explicar pelo autodidatismo de artistas e artífices decorrente da ausência de especialização sistemática. Em geral, artesãos de maior ou menor talento. (SILVA, 1988, p. 25)

No início do século XIX, artífices brancos ainda prevaleciam como licenciados pela Câmara para atuar como mestres e, como tinham escravos, os usavam como seus oficiais e aprendizes. Também trabalhavam com libertos e forros por "jornal", o que significava um pa- 
gamento diário. Logo, ao adquirir conhecimento, os mais hábeis também se tornaram mestres e foram em busca de liberdade. Concomitantemente a essa nova situação do século XIX, a competição gerada pela intensa presença de homens "de cor" (expressão do período) ocupando postos de trabalho diminuía o status dos artífices brancos, que passaram a não ter tantas posses como antes, como exemplifica Leal (1996, p. 61): “[...] os que mantinham uma situação de destaque possuíam ainda, seus instrumentos de trabalho, para a garantia de sobrevivência, e, muito raramente, eram donos de oficinas". Quanto à presença dos negros escravizados, Flexor (1974) afirma que desde o século XIX:

[...] os homens de condição escrava participavam mais das tarefas de acabamento de edificios, móveis, ferragens, etc., assimilando as técnicas, tornando-se rivais de seus próprios mestres de oficio, como observou Debret em relação ao Rio de Janeiro e Koster em Pernambuco. (FLEXOR, 1974, p. 39)

Até este momento não tenho conhecimento de pesquisas documentais que comprovem que os artesãos brancos do século XIX eram a maioria, nem mesmo que era entre eles que se recrutavam contramestres e administradores de grandes obras (a minha memória de tamborete também não tem registro). Mesmo quando as câmaras municipais oficialmente restringiam a aprendizagem e o exercício de certos oficios aos homens "de cor", os mestres brancos, que recebiam as licenças, os tinham como oficiais e aprendizes. Pela bibliografia consultada e pelos relatos dos viajantes, é pouco provável que, ainda no século XIX, permanecesse a dicotomia entre ofícios nobres (realizados por brancos) e oficios rudes (realizados por homens "de cor"), embora alguns autores insistam nessa afirmação, mesmo sem apresentar dados estatísticos baseados em análises documentais.
Há exceções, como Freyre (apud VERGER, 1981, p. 221), segundo o qual os escravizados não só carregavam as ferramentas, como também preparavam as tintas e "[...] os senhores quase não sujavam os dedos". Por outro lado, dentre os estudos consultados, muitos garantem que não era por considerar socialmente degradante o trabalho manual que o branco não queria realizá-lo, e sim por sua predileção pelo ócio, tendo, inclusive, essa observação se tornado uma máxima. A esse respeito, vale atentar para registro de Denis (apud VERGER, 1981, p. 122), que no século XIX trabalhou três anos como empregado do Consulado da França na Bahia, ao dar notícias à sua terra natal:

[...] nada mais difere da nossa classe operária do que os operários brasileiros, sobretudo se eles pertencem à raça branca. Acostumados a ter negros sob suas ordens, e deixando cair sobre eles o cuidado dos trabalhos mais grosseiros, eles sentem tão bem a dignidade da mestria em seus oficios que se manda buscar um marceneiro para consertar um imóvel, um chaveiro para abrir uma porta, ele evitará vir carregando suas ferramentas e só se apresentará vestido de fraque negro e às vezes com chapéu tricórnio.

Vilhena (1969, p. 915) compartilha dessa opinião e, nos seus relatos, a escassez de brancos exercendo ofícios mecânicos justificase porque, além "[...] de serem muito poucas as artes mecânicas [...] em que possam empregar-se, nelas mesmo não o fazem, pelo ócio que professam, e a consequência que daqui pode tirar-se, é que infalivelmente hão de ser pobríssimos". Resta saber se, de fato, podem ser considerados "pobríssimos", como afirma o autor, pois alguns, além de se destacarem pela mestria, principalmente nas "artes liberais", tinham escravos oficiais ao seu dispor.

Preguiça ou status são fatores que, isoladamente, não sustentam nossa opinião sobre o que fez o conhecimento passar de uma mão à outra, mas, alguns fatores combinados levam 
a crer que os oficios mecânicos foram, no século XIX, apropriados majoritariamente pelos homens "de cor". Primeiro, porque era o contingente disponivel para o trabalho manual, e tais oficios constituiam as atividades que lhes restavam numa sociedade segregadora e preconceituosa. Segundo, porque, além de serem minoria, os brancos tinham, na cor da pele, a garantia de mais oportunidades, tal como educação formal e emprego público. Portanto, no Brasil, o último desejo de um oficial mecânico branco seria o de ver seu filho seguindo sua profissão, visto que este, certamente, teria oportunidades mais favoráveis de galgar qualquer outra carreira.

Como exemplificou o artífice Manuel Querino (1913, p. 39), que viveu o século XIX, “[...] quem era medianamente afortunado não admitia que seus descendentes aprendessem um ofício, e, tornaram extensiva essa desconsideração às artes liberais [...]". Terceiro, porque a ocupação do tempo dos homens "de cor" em atividades braçais era vista como uma forma de evitar as transgressões que pudessem cometer e como forma de "civilizá-los". Sobre isso, vejam a consideração de Spix e Martius (1976, p. 65): “[...] os artesãos trabalham com seus próprios escravos pretos, que sob severa disciplina dos seus senhores aprendem, além da habilidade e aptidão no ofício, também a virtude da ordem civil".

\section{Os sujeitos marceneiros, suas oficinas e sociedades}

Maria Helena Flexor ilustrou o seu texto, no catálogo de uma exposição temporária no Museu Afro-Brasil, em 2013, em São Paulo13 ${ }^{13}$ com a aquarela a seguir, que registra o trabalho de um escravizado com instrumentos de castigo atados ao pescoço e ao tornozelo.

13 Exposição: “Arte, adorno, design e tecnologia no tempo da escravidão". (FLEXOR, 2013, p. 55).
Foto 9 - "Ofício de negro - marceneiro".

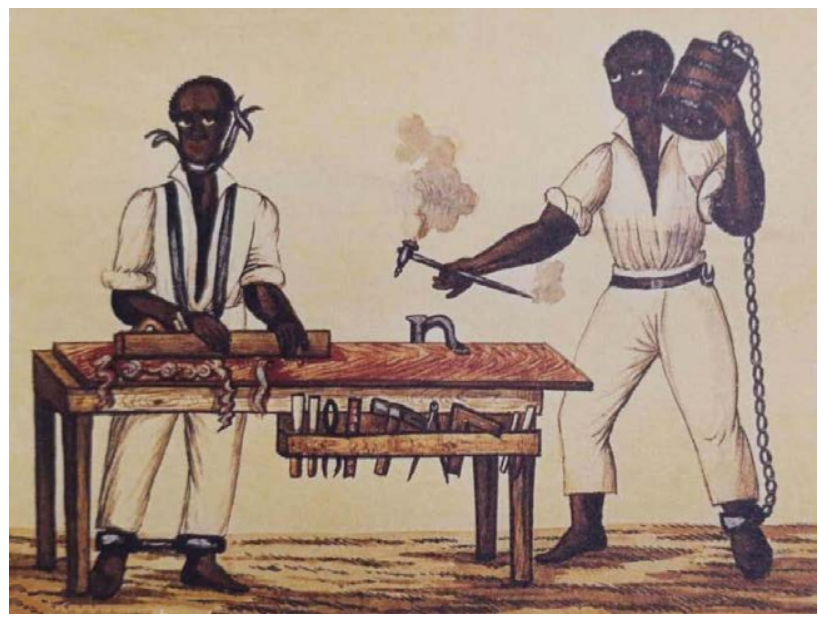

Fonte: "Autor não identificado. Ofício de negro - marceneiro. C. 1829. Aquarela, guache e tinta ferrogálica. Coleção Particular" (FLEXOR, 2013, p. 55).

Essa imagem remete às palavras de Mbembe $(2019$, p. 28$)$ sobre o trabalho escravo:

Como instrumento de trabalho, o escravo tem um preço. Como propriedade tem um valor. Seu trabalho responde a uma necessidade e é utilizado. O escravo, por conseguinte, é mantido vivo, mas em 'estado de injúria', em um mundo espectral de horrores, crueldade e profanidade intensos.

Já pensaram o que era trabalhar, talhar a madeira, nessas condições, que se aproximam do "[...] mundo espectral de horrores, crueldade e profanidade intensos" - destacados por Mbembe. Espero que eu não tenha sido feito em condições semelhantes. Sobre a presença de trabalho escravo nas artes mecânicas, a documentação sobre o exercício dos ofícios fala sobre a presença, em 1800 , do escravo do Pe. Bernardo (Froes) Pereira, Luís Antônio, habilitado aos serviços de marcenaria. Ora, essa constituía uma transgressão à lei vigente, de 1780 , sobre a qual trataremos adiante, pois, legalmente, escravizados eram proibidos de ter licenças para atuar. Havia outros em ofícios diversos. Há registro, em 1793, da presença de Anna M ${ }^{a}$ de Santa Rita; em 1809, de Maria da Trindade; e em 1812, de Izidora Pereira da Conceição na lista de marceneiros dos "Livros das Oficinas (1790-1813)" do Arquivo Público Municipal de Salvador. 
Quanto à existência delas, embora pareça espantoso, ressalte-se que a lei permitia que as viúvas continuassem na liderança das oficinas de seus maridos. Já a presença de sete cativos numa listagem de 318 sujeitos (oficios diversos) é suficiente para atestar não só a ineficiência da proibição legal aos cativos, como também para demonstrar a força que o costume já revelava, ou seja, a própria câmara que emitia a proibição aceitava a violação da lei em sua lista oficial. Ademais, serve para instigar a imaginação sobre a grande quantidade de tantos outros que trabalhavam sem serem licenciados, o que confere ao sistema corporativo baiano uma fisionomia díspar do sistema português. Homens "de cor" não só se inseriram em todo o sistema produtivo como amealharam capital, inclusive desenvolvendo o oficio de marceneiro ${ }^{14}$.

As sociedades mutuárias de artífices e operários surgem nas primeiras décadas do século XIX, no contexto de uma Bahia burocrática e religiosa na qual predominavam as atividades agrícolas voltadas para o comércio, com o braço escravizado como sustentáculo das atividades de produção e uma indústria ainda muito incipiente.

\section{Sociedades de Artífices}

Em 1832, duas sociedades mutuárias foram fundadas na mesma Salvador que, em 1835, assistiu à insurreição dos malês ${ }^{15}$, embora os

14 Sobre a presença de marceneiros negros, é possivel encontrar registros na obra de Marieta Alves (1976) e em documentos do Arquivo Público da Bahia: (APEBA, Seção Judiciária, inventário, Classificação 01-386-744-09); Almanak (1845 e 1898); (APEBA, Seção Judiciária, inventário e testamento, classificação 06-2694-06); (APEBA, Seção Judiciária, inventário, classificação 01-102-15002); (APEBA, Seção Judiciária, inventário, classificação 05-2042-2513-02); (APEBA, Seção Judiciária, inventário e testamento, classificação 06-2592-3092-32).

15 Rebelião ocorrida janeiro de 1835, na cidade de Salvador, na qual não somente negros muçulmanos participaram, mas foi por eles concebida e liderada. Estudo completo pode ser encontrado no livro "Rebeliões escravas no Brasil", do historiador João José Reis. (REIS, J. J. Rebelião Escrava no Brasil; a história do levante artífices que deram origem a estas sociedades já se reunissem havia, pelo menos, dez anos. A primeira a ser criada, em fevereiro, foi a Sociedade dos Artífices, formada originalmente por carpinteiros dispensados do quadro de oficiais mecânicos do Arsenal da Marinha. Nesse sentido, Mattoso (1996) afirma que, até a década de 1830, o Arsenal da Marinha empregava em torno de trezentos artesãos livres. Depois, parece ter reduzido suas atividades, pois, em 1860, tinha apenas onze mestres contratados. Constatou a autora que a indústria da construção naval, que antes fora grande empregadora restrita aos artesãos livres, tinha entrado em decadência.

Numa lista de 71 associados, 50 homens que exerciam as profissões de carapina, calafate, armador, carpinteiro, marceneiro, escultor, ferreiro, ourives, funileiro, dourador, pintor, etc. são relacionados com as seguintes classificações de cor/raça/status social: preto, crioulo, mestiço, pardo, cabra, africano liberto, crioulo livre, pardo livre, e livres - segundo tabela apresentada por Silva (1988). Contando com cerca de $70 \%$ de homens "de cor" no seu quadro social desde a fundação, esta era uma associação de trabalhadores livres e libertos.

Sete meses depois da criação da Sociedade dos Artífices, o africano livre Manoel Victor Serra, que tinha a profissão de ganhador, junto a outros negros do chamado "canto da Preguiça", na cidade de Salvador, também fundou, em 16 de setembro, a Sociedade Protetora dos Desvalidos - S.P.D. Essa sociedade era uma agremiação que não usava de meios-termos para tornar evidente sua distinção racial (as figuras 12 e 13 ilustram esta distinção). Para admissão, segundo o Artigo 33 do Compromisso da Sociedade, aprovado em 1833, o candidato deveria ser, segundo Braga (1987, p. 19): “[...] necessariamente de côr preta e que não houvesse a menor dúvida a esse respeito".

dos Malês em 1835. São Paulo: Cia. das Letras, 2003). 
Somente entre os 15 sócios-fundadores com profissão declarada, seis (6) eram marceneiros, inclusive seu fundador, Manoel Serra. Havia também um pedreiro, dois carroceiros, um carregador de água, um vinagreiro, dois ganhadores e um pedreiro, sendo que este ocupava o cargo de "escrivão definidor". Muitos negros e negras que aqui desembarcavam já traziam conhecimentos artísticos, como foi o caso dos marceneiros, que ao serem iniciados em determinados oficios mostravam-se habilidosos e aptos a desempenhar, com suas próprias mãos, as encomendas. A linha que separa habilidade e criação é muito tênue e, não raro, em uma cópia pode haver recriação, principalmente sendo fruto da atividade humana manual.

A Sociedade Protetora dos Desvalidos, como sociedade civil propriamente dita, passou a existir, com a denominação que mantém até hoje, com o fim de promover a beneficência entre trabalhadores livres negros. Era, sobretudo, uma associação de artífices das artes mecânicas, principalmente marceneiros, como bem ressalta a figura 12 , na sequência, que destaca o serrote e o martelo, elementos indispensáveis à construção arquitetônica, de mobiliário e de ornamentações artísticas, e que decoram a parede da sua sede no Largo do Cruzeiro de São Francisco, no 82 , no centro antigo de Salvador, onde permanece até hoje.

Os sujeitos produtores não somente atendiam as demandas comerciais, também se associavam e formavam novos mestres e aprendizes da arte da marcenaria, pois, como bem atenta Olivella: "[...] o negro teve que fabricar sua própria bússola, improvisando-a a partir de sua dor, de sua memória ancestral, de seu poder criador. Foi o que fez com sua filosofia, seus mitos e experiências" (1999, p. 110.) ${ }^{16}$. Vinte e nove anos depois de Olivella, a obra de

16 Tradução nossa do original: “[...] el negro debió fabricar su propia brújula, improvisándola a partir de su dolor, de su memoria ancestral, de su poder creador. Fue lo que hizo con su filosofia, sus mitos y experiencias."
Mbembe (2018, p. 95) ratifica o argumento do poder criativo de pessoas em situação de cativeiro: “[...] Inventaram suas próprias literaturas, músicas, maneiras de celebrar o culto divino. Foram obrigados a fundar suas próprias instituições - escolas, jornais, organizações políticas [...]". Por isso, ao falar dos sujeitos produtores do mobiliário dos períodos colonial e imperial, não é possível dissociá-los da sociedade escravocrata que enriqueceu com a força do trabalho escravo.

Figura 10 - Retrato, óleo sobre tela, do artífice Felipe Barreto da S.P.D.

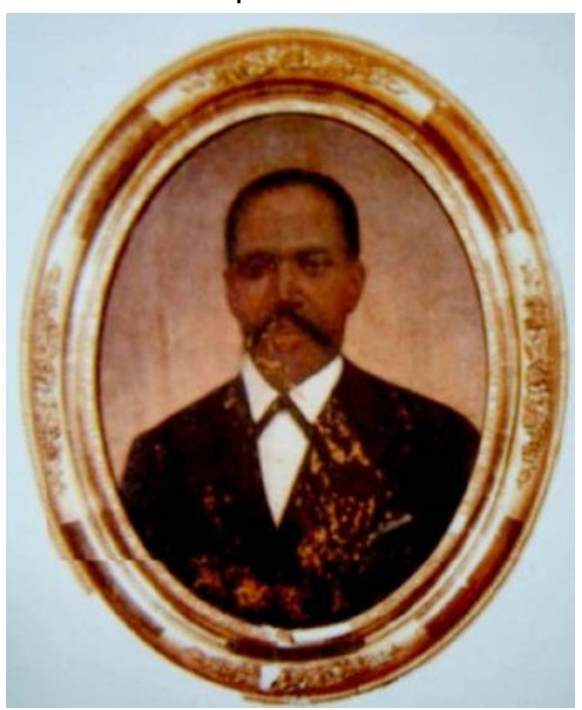

Foto: Lysie Reis, 2012.

Figura 11 - Retrato, óleo sobre tela, do artífice José Maria de Freitas da S.P.D.

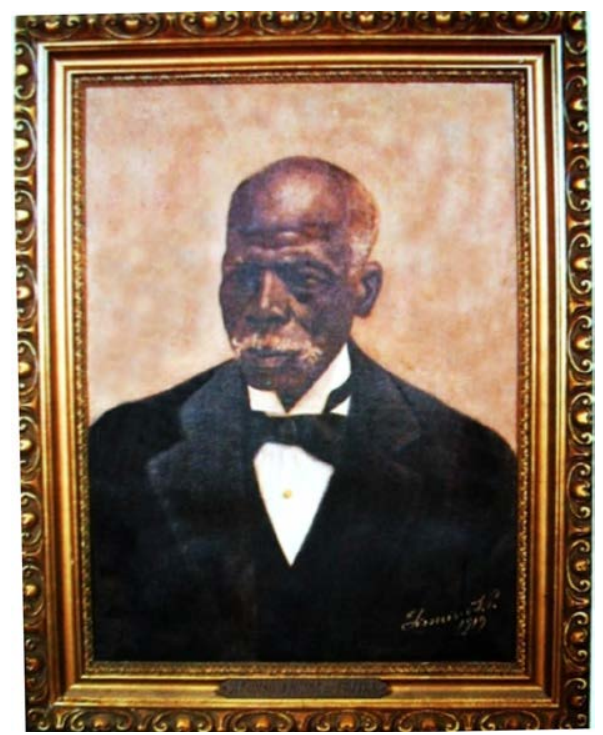

Foto: Lysie Reis, 2012. 
Figura 12 - Pintura parietal, destacando o serrote e martelo, sede da S.P.D.

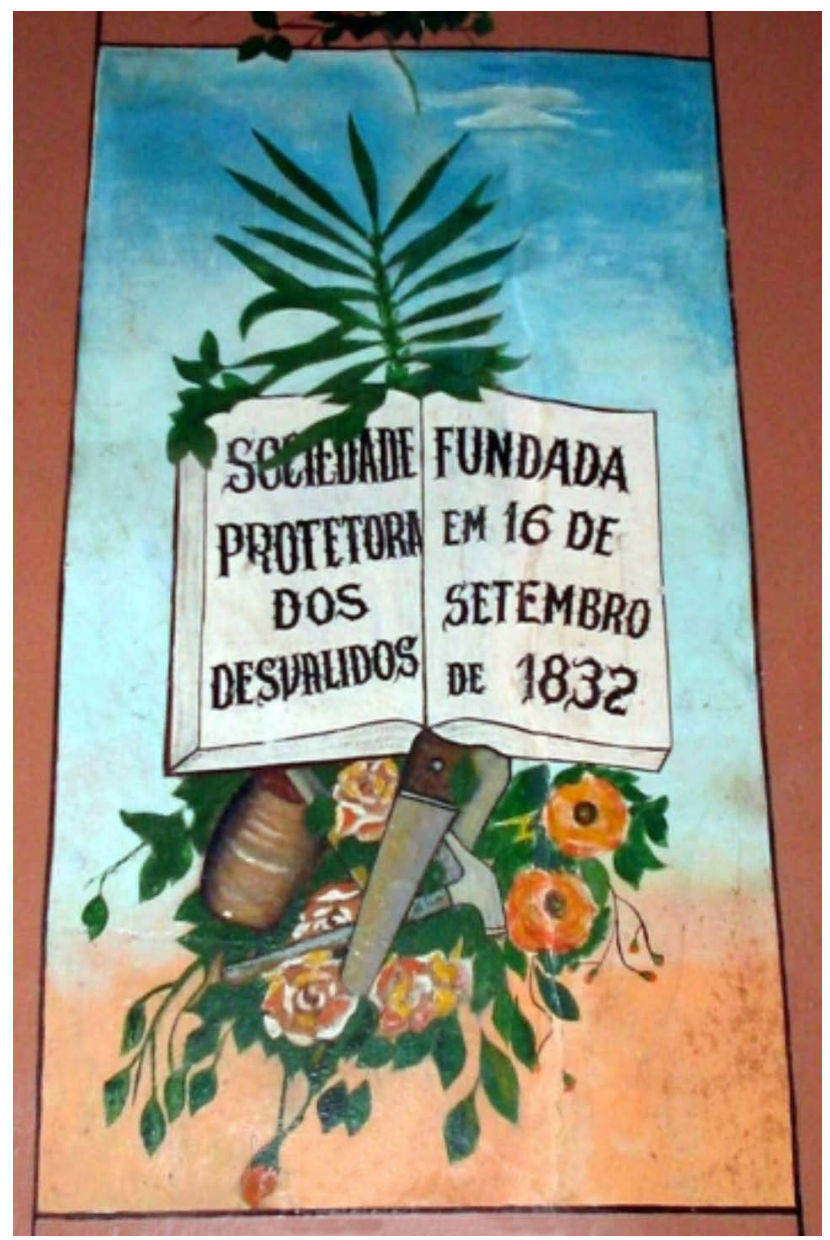

Foto: Lysie Reis, 2002.

Vocês, humanos, precisam entender que além de nos permitir falar, mesmo que esporadicamente, precisam também dar visibilidade às memórias e histórias sobre as pessoas que compuseram o que se consagrou chamar de "mão de obra africana e afrodescendente"; é preciso, como lembra a escritora Cruz: “[...] trabalhar para apagar as linhas divisórias que por tantos séculos nos deixaram à parte do banquete principal do país. [...] (2018, p. 304)". A expressão pluralizada "nos deixaram", utilizada pela autora, refere-se à descendência das pessoas escravizadas que construíram este país, mas essa expressão também vale para mim, que sou objeto, e para todas as pessoas que ainda estão à margem dos diversos "banquetes" deste país.

\section{Chegando ao final: reflexões sobre como romper silêncios}

[...] Estas palavras nomeiam a consistência do vazio. No silêncio do cenário, sobre a poeira muda que cobre os objetos, as palavras libertas do espírito traçam sinuosas pistas, reúnem e recompõem a vida esmigalhada dispersa pelo tempo. Empírico, o cenário é uma memória viva. E se alma se escondesse no inanimado para escapar aos danos do tempo?

(DIOME, 2008, p. 29).

Os cenários expográficos são aparentemente silenciosos, pois os objetos são “[...] aparentemente mudos", como sinaliza Mbembe (2018, p. 223). Para romper silêncios é preciso estabelecer diálogos. Os mudos objetos falam a partir dos documentos, interpretados pelas pessoas que estão envolvidas com seu estudo, como salienta Meneses: "[...] é o historiador quem fala e a explicitação de seus critérios e procedimentos é fundamental para definir o alcance de sua fala. [...]" (1997, p. 7). Portanto, através de processos de pesquisa é possivel "ouvir" vozes do passado distante e recente, relativo ao mobiliário.

Novas pesquisas são necessárias para que seja possivel explicitar as memórias do trabalho de marcenaria, os seus sujeitos, associações, as oficinas e cantos de trabalho, as ferramentas e equipamentos, as leis de regulamentação e suas proibições, os métodos e materiais empregados, o comércio e as interdições, os transportes, as interdependências da cadeia de produção, entre outros argumentos que possam incluir a dinâmica da vida social dos objetos, de forma a enriquecer não somente os dados de documentação, mas as diversas ações museológicas, tais como a exposição e as ações educativas com o patrimônio, como sugere Blanco, “[...] Mas, acima de tudo, porque envolve a aquisição e o domínio 
de alguns instrumentos ou ferramentas de conhecimento, de destreza e habilidades e, até mesmo, e talvez essa seja o mais importante, uma atitude crítica fundamental como bagagem educacional" (1994, p. 13).

Os sujeitos marceneiros associavam-se coletivamente. Ainda que individualmente muitos permaneçam no anonimato, essas informações relativas à produção mobiliária poderiam ser disponibilizadas ao público. Passado e presente se interconectam na busca de traços biográficos do mobiliário do MAB, composto por diversas vozes, que podem revelar vidas humanas implicadas na produção, no uso e na musealização, através de interpretações e apreensões sobre os artífices e suas práticas sociais, com suas identidades e continuidades do "saber-fazer".

O mobiliário do $M A B$, pelos seus muitos anos de homogenia expositiva, apresenta características que o aproximam de uma estabilidade expositiva, baseada na repetição dos espaços domésticos das classes dominantes da cidade de Salvador e da região do Recôncavo, região açucareira que propiciou o luxo e a exuberância dos móveis, às custas do trabalho escravo. No entanto, a ênfase informacional está nas características intrínsecas, a exemplo da tipologia funcional, tipo de madeira e outros elementos, como metais e marfim, que fazem parte da composição; o período de elaboração e uso, e o estilo - são informações válidas para quem possui conhecimentos mínimos sobre esses assuntos. Faltam informações extrínsecas, que ofereçam ao público dados biográficos dos objetos. 0 atual formato expográfico, baseado em pequenas etiquetas, consolida a mudez dos objetos.

Sair da homogenia e da estabilidade expositiva não é uma tarefa fácil, pois exige posturas críticas para a inclusão da polifonia e da heterogeneidade expositiva. É necessário perguntar o porquê e o para que se preserva, como chamam atenção as palavras de Cunha e Freitas (2018, p. 559): “[...] Este é o principal desafio da preservação, provocar sensibilidades e empatias. Mas, ainda assim, ultrapassada essa barreira, é necessário que se reflita não apenas sobre o que é preservado, mas, sobretudo, porque e para que se preserva".

Não há receitas para sair dos silêncios. Processos de pesquisa podem ser evocados e desenvolvidos como forma de provocar a "escuta" das diversificadas "vozes" dos objetos, aproximando objetos da cultura material das relações humanas, pois estes carregam em si potenciais de informações, que lhes dão sentido material e simbólico.

As reflexões aqui apresentadas visam a valorização do mobiliário do MAB, através da incorporação de elementos que os aproximem do público visitante, através de elementos expográficos que ofereçam elos com a historicidade dos objetos, ultrapassando os dados visíveis, como propõe o historiador da arte Didi-Huberman (2017, p. 67): “A história da arte não conseguirá compreender a eficácia visual das imagens enquanto continuar entregue à tirania do visivel [...]". O prazer estético provocado pelos móveis e pelos demais objetos de arte decorativa expostos no MAB não será eliminado com a incorporação de componentes críticos e analíticos que podem contextualizar a expografia. Ao focar no visivel dos objetos, ou seja, somente nos aspectos intrínsecos, 0 museu silencia as vozes humanas produtoras e consumidoras dos objetos.

Uma vez que esta narrativa memorial começou sob a inspiração de uma escritora senegalesa, vou finalizar com o filósofo Souleymane Bachir Diagne, também senegalês, que pondera sobre a necessidade de se diminuir as distâncias entre a objetividade e a subjetividade que os objetos carregam, em reflexão acerca de análise de Léopold Sédar Senghor sobre pensar o objeto de forma simétrica: 
[...] uma abordagem cognitiva que, por simetria, seria preciso chamar de sintética: aquela que nos instala imediatamente no coração do objeto (que deixa então de ser definido em uma dualidade com o sujeito), no coração daquilo que o constitui em sua 'subjetividade' e que é seu ritmo próprio. Compreende-se, então, o jogo de palavras que Senghor frequentemente utiliza quando fala do pensar o objeto como uma maneira de dançá-lo. (DIAGNE, 2018, p. 15, grifos do autor).

Eu, tamborete, em minha existência material na exposição do $M A B$, necessito dessa dimensão simétrica. Nós, objetos, necessitamos ser pensados também de forma dançante, ou seja, as expografias precisam ser vibrantes, de forma a explicitar as subjetividades. Por nossa materialidade, somos tangiveis, mas os elementos intangiveis que carregamos necessitam de visibilidade, através de processos expográficos que explicitem os sujeitos produtores que dominaram matérias-primas e técnicas construtivas; assim como explicitar os modos de uso e de musealização. Enfim, a visibilidade da historicidade dos objetos permite ampliar a empatia entre o público e o acervo.

As reflexões aqui suscitadas passam por dinâmicas entre as memórias dos sujeitos produtores do passado, sem esquecer a permanência dos sujeitos artífices que continuam, com muitas dificuldades, mantendo as técnicas do saber-fazer das artes mecânicas. Mesmo com a oportunidade de narrar os inúmeros caminhos de um tamborete, não se pode perder de vista que o maior patrimônio não somos nós, objetos, mas vocês, seres humanos, que são, de fato, a razão para a produção e continuidade dos objetos.

\section{Referências}

ALBERTI, S. J. M. M. Focus museums and the history of science; Objects and the museum. Isis, 96, 559-571. 2005. Disponivel: https://www.research.manches- ter.ac.uk/portal/en/publications/focus-museums -and-the-history-of-science--objects-and-the-museum(f054e1ce-f7ce-4f9c-9e32-3e1e4a932d23).html Acesso em: 29/10/2019.

ALMANAK Administrativo, Indicador e Noticioso do Estado da Bahia, v. 1, Bahia, 1845.

ALMANAK Administrativo, Indicador e Noticioso do Estado da Bahia, v. 1, Bahia, 1898.

ALVES, Marieta. Dicionário de artistas e artífices

na Bahia. Salvador: Centro Editorial e Didático da UFBA, 1976.

APPADURAI, Arjun. A vida social das coisas; as mercadorias sob uma perspectiva cultural. Trad. Agatha Bacelar. Niterói: Editora da Universidade Federal Fluminense. 2008.

APEBA - Arquivo Público do Estado da Bahia. Seção de Arquivo Colonial e Provincial. Seção Judiciária.

Bahia, Le marché. Mercier, fototipia, [S.l.], 1902. Acervo Ubaldo Senna Filho. Fotografia recebida via: REBOUÇAS, Daniel. Publicação eletrônica [mensagem pessoal]. Mensagem recebida por joseaniafreitas@yahoo.com.br, em 18 de dez. de 2019a.

BAKHTIN, Mikhail. A cultura popular na Idade Média e no Renascimento; o contexto de François Rabelais. Trad. Yara Frateschi. São Paulo: Hucitec, 1987.

BAXANDALL, Michael. 0 olhar renascente; pintura e experiência social na Itália da renascença. Trad. Maria Cecília P. R. Almeida. Rio de Janeiro: Paz e Terra, 1991.

BRAGA, Júlio Santana. Sociedade Protetora dos Desvalidos: uma irmandade de cor. Salvador: Inamá, 1987.

CANTI, Tilde. 0 móvel no Brasil; origens evolução e características. Lisboa: Agir, 1999.

CARVALHO, Antonio José de; DEUS, João de. Dicionário prosódico de Portugal e Brasil. 5a ed. Rio de Janeiro: Lopes e Schmidt, 1895.

CUNHA, Marcelo Nascimento Bernardo da; FREITAS, Joseania Miranda Freitas. Mapas individuais e coletivos de memórias e identidades. In: FILIPE, 
Graça; VALE, José; CASTAÑo, Inês. Patrimolialização e sustentabilidade do património; reflexão e prospectiva. Lisboa, IHC-NOVA FCSH, 2018. Disponivel em: https://estudogeral.sib.uc.pt/bitstream/10316/81719/1/Universidade\%20de\%20Coimbra_Alta\%20e\%20Sofia.pdf Acesso em: 29/9/2019.

CRUZ, Eliana Alves. Água de Barrela. Rio de Janeiro: Malê, 2018.

DIAGNE, Souleymane Bachir. Bergson pós-colonial; o elã vital no pensamento de Léopold Sédar Senghor e Muhammad Iqbal. Trad. Cleber Daniel Lambert da Silva. Desterro (Florianópolis): Cultura e Barbárie, 2018.

DIDI-HUBERMAN, George. Diante da imagem. Trad. Paulo Neves. São Paulo: Editora 34, 2013. (2a reimpressão 2017).

DIOME, Fatou. Kétala. Trad. Rita Bueno Maia. Lisboa: Europress, coleção Raízes. 2008.

FLEXOR, Maria Helena Ochi. Oficiais mecânicos na cidade do Salvador. Salvador: Prefeitura Municipal. Departamento de Cultura, 1974.

FLEXOR, Maria Helena Ochi. Os ofícios mecânicos e os escravos. In Arte, adorno, design e tecnologia no tempo da escravidão. Curador Emanuel Araújo. São Paulo: Museu Afro Brasil, 2013.

FREITAS, Joseania Miranda. Escravidão: tema tabu para os museus de arte decorativa. Revista PerCursos, Florianópolis, v. 20, n. 44, p. 56 - 76, set./dez. 2019. Disponivel em: http://www.revistas.udesc.br/index. php/percursos/article/view/1984724620442019056 Acesso em: 30/3/2020.

GARCÍA BLANCO, Ángela. Dicdática del museo; el descubrimiento de los objetos. Madrid: Ediciones de la Torre. 1994.

GELL, Alfred. Arte e agência; uma teoria antropológica. Trad. Jamile Pinheiro Dias. São Paulo: Ubu Editora, coleção Argonautas, 2018.

GINZBURG, Carlo. 0 queijo e os vermes. Trad. Maria Betânia Amoroso; trad. dos poemas José Paulo Paes. São Paulo: Companhia das Letras, 2006.
INGOLD, Tim. Estar vivo; ensaios sobre movimento, conhecimento e descrição. Trad. Fábio Creder. Petrópolis-RJ: Vozes, 2015 (Coleção Antropologia), 2a reimpressão, 2018.

KOPYTOFF, Igor. A biografia cultural das coisas: a mercantilização como processo. In APPADURAI, Arjun. A vida social das coisas; as mercadorias sob uma perspectiva cultural. Trad. Agatha Bacelar. Niterói: Editora da Universidade Federal Fluminense. 2008.

LEAL, Maria das Graças de Andrade. A arte de ter um ofício; Liceu de Artes e Ofícios da Bahia (1872-1996). Salvador: Fundação Odebrecht / Liceu de Artes e Ofícios da Bahia, 1996.

MAB - O Museu de Arte da Bahia. São Paulo: Banco Safra. Catálogo. 1997.

MBEMBE, Achille. Crítica da razão negra. 2a ed. Trad. Sebastião Nascimento. São Paulo: n-1 edições, 2018.

MBEMBE, Achille. Necropolítica; biopoder, soberania, estado de exceção, política da morte. Trad. de Renata Santini. São Paulo: n-1 edições, 2018, 3a reimpressão, 2019.

MATTOSO, Kátia M. de Queiroz. Bahia, Século XIX; uma Província no Império. Tradução Yedda de Macedo Soares. 2a Ed. Rio de Janeiro: Nova Fronteira, 1996.

MENESES, Ulpiano B. de. Memória e cultura material: documentos pessoais no espaço público. [SL], 1997. In: Revista de Estudos Históricos. V. 11, N. 21, 1998. Disponivel em: <http://bibliotecadigital.fgv.br/ojs/ index.php/reh/article/view/2067/1206> Acesso em: 30/10/2019.

MOLES, Abraham A. Teoria dos objetos; teoria dos objetos. Trad. Luíza Lobo. Rio de Janeiro: Edições Tempo Brasileiro, 1981.

QUERINO, Manuel. As Artes na Bahia. Esboço de uma contribuição histórica. 2a edição. Bahia: Oficina do Diário da Bahia, 1913.

PINHO, Wanderley. História de um engenho no Recôncavo. 2a ed., il. e acrescida de um apêndice. São Paulo: Ed. Nacional; Brasília: Fundação Nacional 
Pró-Memória, 1982.

REBOUÇAS, Daniel. Publicação eletrônica [mensagem pessoal]. Mensagem recebida por joseaniafreitas@yahoo.com.br, em 18 de dez. de 2019a.

REBOUÇAS, Daniel. Publicação eletrônica [Rede Social Instagram]. Disponivel em: https://www.instagram.com/daniel.reboucas.historia/ Acesso em $18 / 12 / 2019 b$.

REIS, J. J. Rebelião escrava no Brasil; a história do levante dos Malês em 1835. São Paulo: Cia. das Letras, 2003.

REIS, Lysie. A liberdade que veio do oficio; práticas sociais e cultura dos artífices da Bahia do século XIX. Salvador: EDUFBA, 2012.

REIS, Lysie. Homens rudes e muito honrados dos mesteres; as organizações de trabalhadores das artes mecânicas em Portugal antes do século XIX. Salvador: EDUNEB, 2019.

ROCHA, Carlos Eduardo da. 0 mobiliário antigo na Bahia. 3a ed. Salvador: Itapuã, 1977.

SANTOS, José de Almeida. Mobiliário artístico brasileiro. São Paulo: Elvino Pocai, 1944.

SILVA, Maria Conceição Barbosa da Costa e. 0 Montepio dos Artistas; elo dos trabalhadores em Salvador. Coleção Selo Editorial Letras da Bahia. No 28. Salvador: Secretaria da Cultura e Turismo do Estado da Bahia / Fundação Cultural, EGBA, 1988.

SOARES, Cecília Moreira. Mulher negra na Bahia no Século XIX. Dissertação. Programa de Pós-Gradua- ção em História, Faculdade de Filosofia e Ciências Humanas, UFBA. 1994. Disponivel em: https://ppgh. ufba.br/sites/ppgh.ufba.br/files/1994._soares_cecilia_moreira._mulher_negra_na_bahia_no_seculo_xix.pdf Acesso: 16/11/2019.

SPIX, Johann Baptist Von; MARTIUS, Carl Friedrich Philipe Von. Viagem pelo Brasil. 3a ed. 3 vols. São Paulo: Melhoramentos, 1976.

VERGER, Pierre. Notícias da Bahia de 1850. Coleção Baianada. Salvador: Corrupio, Fundação Cultural da Bahia, 1981.

VILHENA. Luís dos Santos. A Bahia no século XVIII. Vol. III. Carta XXIV. Coleção Baiana, Salvador: Itapuã, 1969.

The Vendor. Série ARA, (S.L.). c. 1920. Library of Congress, New York City. Disponivel em: https://www. instagram.com/daniel.reboucas.historia/ Acesso em 18/12/2019b.

TINHORÃO, José Ramos. Os negros em Portugal; uma presença silenciosa. Lisboa: Editorial Caminho, 1988.

ZAPATA OLIVELLA, Manuel. Las claves mágicas de América. 2a ed. Bogotá: Plaza y Janes, 1999.

\section{Documentos do Museu de Arte da Bahia}

Fichas de documentação do tamborete, assinada por VALLADARES, José. (1948).

Recebido em: 06.03.2020

Revisado em:06.05.2020

Aprovado em: 28.05.2020

Joseania Miranda Freitas é Doutora em Educação (UFBA), com pós-doutorado em História (Programa de Estudos PósGraduados em História da PUC-SP 2016-2017) e pós-doutorado em História (UFG/UNINORTE-Colômbia/UPVD-Perpignan-França 2006-2007). Professora Titular do curso de Museologia da UFBA e do Programa de Pós-Graduação em Museologia/PPGMuseu/UFBA. E-mail: joseaniafreitas@yahoo.com.br

Lysie dos Reis Oliveira é Doutora em História Social (UFBA). Com pós-doutorado na Universidade do Porto, no Centro de Pesquisa em Arquitetura e Urbanismo (CEAU), Professora titular do Departamento de Ciências Humanas I, da Universidade do Estado da Bahia (UNEB). Líder do Grupo de Pesquisa: Estudos Interdisciplinares em Desenho. Linha de pesquisa: memória visual e desenho urbano. E-mail: lysie60@hotmail.com 